\title{
Borneo and its disproportionately large rheophytic aroid flora
}

\author{
P.C. Boyce ${ }^{1} \&$ S.Y. Wong ${ }^{2,3}$ \\ ${ }^{1}$ Ludwig-Maximilians-Universität München, Department Biologie I, \\ Systematische Botanik und Mykologie, \\ Menzinger Straße 67, 80638 München, Germany \\ boyce@biologie.uni-muenchen.de \\ ${ }^{2}$ Faculty of Resource Science \& Technology, Universiti Malaysia Sarawak, \\ 94300 Kota Samarahan, Sarawak, Malaysia \\ sywong@unimas.my \\ ${ }^{3}$ Harvard University Herbaria, 22 Divinity Avenue, \\ Cambridge, MA 02138, U.S.A. \\ sywong@fas.harvard.edu
}

\begin{abstract}
On the basis of decades of field observations and multidisciplinary research, in particular directed at species of Araceae exhibiting rheophytism, we offer an overview of morphological diversity among the more than 130 aroid species so adapted on Borneo. Based on a combination of morphological and concomitant ecological occurrence, a preliminary scheme of subcategories of van Steenis" "rheophytic landplants" is outlined with the purpose of encouraging study to better understand the impetus of obligate rheophytic aroids' evolution. It is hoped that the proposed subcategories will encourage targeted research with abundant field-based observations. Criticism is directed at the current demand by scientific journals that computer algorithm-generated statistical 'proof' be provided for all observational life science writing and further insisting that all such observations be linked to a 'big picture' by comparison within the context of a global perspective, preferably incorporating whatever themes are currently fashionable in the field. Such requirements discourage researchers, and particularly students, from undertaking purely observational research, and effectively result in the suppression of publication of vital observational data while encouraging publication of statistically well-supported biological nonsense.
\end{abstract}

Keywords. Araceae, geology, morphological adaptations, rheophytism, river basins

\section{Introduction}

Predictably it was the ever-observant H.N. Ridley (1855-1956) who first drew notice to the existence of riverbank and streambed plants in Peninsular Malaysia with narrow leaf blades morphologically well-suited to sudden rises in and buffeting by flood waters associated with rain storms (Ridley, 1893: 269-270). Later, the famed Italian botanist-explorer Odoardo Beccari (1843-1920) made comparable observations in Borneo, seemingly independently of Ridley (or at least without citing him) and employed, as did Ridley albeit indirectly, the term stenophyllous (stenofillia in Beccari's original Italian) for the life-form (Beccari, 1902: 412-413, 523-525, fig.65 \& 1904: 305, 392-393, fig.51). Other early observations on Bornean rheophytes are 
those of Dakkus (1925), Endert (1927) - writing up the expedition that had resulted in the only ever collection of what remains to this day ones of the biggest rheophytic aroids, Bucephalandra gigantea Bogner - and one of the pioneers of modern Bornean Dipterocarpaceae taxonomy, D.F. van Slooten (1928). It was left to the everinventive phytogeographer, taxonomist, and founder of the Flora Malesiana project, C.G.G.J. van Steenis (1901-1986), to coin the term rheophyte (van Steenis, 1932: 174), and later (van Steenis, 1948) used the word while describing a new species of Acanthaceae. He then went on to produce a much-overlooked essay on the topic of rheophytism (van Steenis, 1952), and a brief account of rheophytic plants in South Africa (van Steenis, 1978), before establishing his mastery of the subject with a hefty book (van Steenis, 1981), and a weighty supplement (van Steenis, 1987). In total van Steenis listed 77 angiosperm families and 728 rheophytic species, of which one family, the Podostemaceae, accounts for 250 species, plus an additional 41 species of fern and fern allies, and three species of gymnosperms.

The narrow leaf blades upon which Ridley and Beccari remarked are the most apparent adaptation exhibited by rheophytic plants, but are just one characteristic of a suite, some obvious (e.g., slender supple branches, and a disproportionately extensive root system), other less so (e.g., free ligular petiolar sheaths, splash-cup dispersal, swiftly germinating seeds employing a mechanism for anchorage, blooms produced during drier months, or in some manner presented to protect them from sudden onrushes of water). Our combined 35 years of research on Bornean Araceae, a family pre-eminently representative of rheophytism here, have revealed a wealth of such combined morphologies and have enabled a better than rudimentary understanding of how the various component parts function holistically, as well as having provided clues, some clear others less so, as to why Borneo is so conducive to rheophytism and in particular to rheophytic aroids [see Wong (2013), Wong \& Boyce (2013), and Low et al. (2016)].

\section{Borneo aroid flora}

At the time of writing, the aroid flora for Borneo amounts to slightly more than 400 described species with a further 140 or so species differentiated but yet to be formally named, allocated to 54 genera (Boyce \& Croat, 2011 onwards). Twenty-six of these genera are endemic on Borneo, or nearly so - two near-endemics have extensions to the Anambas Islands (Nabalu S.Y.Wong \& P.C.Boyce) and the Riau Archipelago (Colobogynium Schott). Twenty-three of the 54 genera, totalling 121 described and 12 undescribed species of tribe Schismatoglottideae (Wong et al., 2010), are composed entirely of obligate rheophytes. Moreover, all 23 of these genera are endemic on Borneo. In addition, three widespread genera, Homalomena Schott, Rhaphidophora Hassk., and Schismatoglottis Zoll. \& Moritzi contribute 28 more species of obligate rheophyte to the Bornean flora. In consequence a little under one third of all aroid species on Borneo are obligate rheophytes, and almost half of Bornean aroid genera are partially to entirely composed of obligate rheophytes. These percentages considerably 
exceed the corresponding quotients of rheophytic aroids (genera and species) of any other place on earth, and although we do not have precise figures readily to hand, owing to there being almost no reliable published accounts for the rheophytic flora of the rest of Asia, [the sole exceptions being Hay $(1990,1999)$ for New Guinea, and Puff \& Chayamarit (2011) for Thailand], we consider it highly improbable that any plant family has a greater proportion of obligate rheophytes on Borneo, or elsewhere come to that, than do the aroids. In Asia the next richest (if that term may be employed for what is, compared to Borneo, a vanishingly small proportion of the total number) areas in terms of rheophytic aroids are Sumatera [one obligate rheophytic genus, Furtadoa M.Hotta (with two species), one endemic species of Apoballis Schott A. okadae (M.Hotta) S.Y.Wong \& P.C.Boyce, two Rhaphidophora - endemic $R$. araea P.C.Boyce and the widespread $R$. beccarii (Engl.) Engl., and about 10 species of Homalomena (Chamaecladon clade)]; Peninsular Malaysia and the southern extremity of the Isthmus of Kra [two species of Kiewia S.Y.Wong \& P.C.Boyce, Rhaphidophora beccarii, and about 10 species of Homalomena (Chamaecladon)]; Sulawesi [two species of Schismatoglottis, and one species of Homalomena (Chamaecladon)], and New Guinea [the monospecific genus Holochlamys Engl. and four described Homalomena (Chamaecladon)].

\section{Schismatoglottideae}

Had this essay been written shortly after publication of the last monographic treatment of the Schismatoglottideae (Hay \& Yuzammi, 2000; Bogner \& Hay, 2000) we would have likely recognised only five genera in which some or all species are rheophytic - Aridarum Ridl., Bucephalandra Schott, Phymatarum M.Hotta, Piptospatha N.E.Br. , and Schismatoglottis. Subsequently, it has become evident (see Low et al., 2018) that over-reliance on 'characters' such as 'thecae horns' (straight, curved or hooked horn-like, peg-like or needle-like extensions of the thecae through which the pollen is expressed), and 'excavated stamens' (variously hollowed or elaborated connective and filament tissues), has resulted in heterogeneous genera. This became ever more apparent as extensive fieldwork revealed a wealth of undescribed species that challenged taxonomic placement into pre-existing genera, ultimately forcing reexamination of the generic boundaries proposed by Bogner \& Hay (2000).

Although we frequently despair at the slavish acceptance of phylogeny reconstructions resulting from 'molecular' analyses that pervades much of biological sciences, we nevertheless recognise that the approach does provide a convenient means to generate taxon groupings independently of morphological characteristics, enabling the occurrence and distribution of morphological features to be better examined ('mapped' in the cladists' terminology) unbiased by pre-conceived perceptions of homology, and permitting insights into potential homoplasy and the reliability, or otherwise, of the morphologies used to define species groupings. Investigation of Schismatoglottideae in this manner (Low et al., 2011, 2014; Ting et al., 2012) made it plain that not only are many of the hitherto unchallenged floral 'characters' used in Schismatoglottideae 
genera unreliable, they are also gravely misleading when examined in isolation rather than as part of, and in the context of, the entire floral structure - the 'thecae horns' and 'excavated stamens' mentioned earlier being among the worst examples, but others exist. Furthermore, Schismatoglottideae abounds with subtle floral morphologies obscured by much of the previous taxonomic work having been largely undertaken, by necessity, from preserved specimens in which detail was difficult to observe. Our ready access to plants in their habitat and to an extensive cultivated collection has been pivotal in making progress in the tribe with one of the most important contributions provided by observing plants flowering in situ and being able to witness the roles of the various parts of the bloom and their interactions with pollinators.

To take complex and functionally often subtle floral biology observations as an example, it verges on tragic that, while so critical to better understanding the functions of the various parts of the bloom and the means by which the senescence mechanics (e.g., Boyce \& Wong, 2007) plays a role in managing pollinator movement, in the current climate of scientific journals demanding computer algorithm-generated 'proofs' of multiple data sets, observational data are frequently deemed unsuitable for publication without data-massaging, even when unsuited to that process. This, coupled with a pervasive editorial requirement for statistically 'proving' complex observations, overlooks the fact that in the forested wet tropics a species population, not infrequently the only known population, often contains fewer than 10 mature individuals and is quite unsuitable for statistical analysis. It is sobering to consider that had such publication constraints been applied when Ridley (1890, 1904), Van der Pijl (1937), Van der Pij1 \& Dodson (1966), Dressler (1968), and to take more recent examples from the aroids, Young $(1986,1988 \mathrm{a}, \mathrm{b})$ and Beath $(1996,1999)$, produced what remain cornerstones in their respective fields, it is almost guaranteed that these papers would not have been accepted for publication. It is encouraging to perceive the first glimmers of caution from within the scientific community (Amrhein et al., 2019) about over-reliance on statistical analyses and the innate risk that illogical results, with good statistical 'support' may convince referees unfamiliar with the group under discussion.

Another benefit of an active field programme is that by considerably enlarging the number of known species, notably Bucephalandra (Boyce \& Wong, 2012, 2014; Wong \& Boyce, 2014, 2016a; Wong et al., 2018) and Aridarum sensu Bogner \& Hay (2000) (Wong \& Boyce, 2007, 2015, 2017; Wong et al., 2012, 2014a,b; Boyce \& Wong, 2013a), we are in a better position to map and evaluate the distribution of species groups (and ultimately genera) and generate biogeographical and ecological data to supplement the understanding of shared morphologies that the molecular analyses enabled. Together these factors need to be employed in understanding rheophytism, an ecological niche that inevitably favours species with syndromes of morphological adaptations fundamental to their survival but which outwardly easily lure the observer into considering the peculiarities as homologous similarities whilst forgetting the environment that set in motion the favouring of these morphologies in the first place - and all the more so when working on preserved material far-removed from the habitat in which it was gathered (and, as so often the case, with minimal observational notes to augment understanding). 


\section{Bornean aroid rheophyte richness}

Why does Borneo support the so extraordinarily rich and diverse rheophytic aroid flora outlined above, and why are so many rheophytic aroid species so highly localised? In many instances species (and some genera) are known from a single locality wherein it is impossible to walk without stepping on the plants - Bakoa lucens (Bogner) P.C.Boyce \& S.Y.Wong, Bidayuha crassispatha S.Y.Wong \& P.C.Boyce, Bucephalandra forcipula S.Y.Wong \& P.C.Boyce, B. kishii S.Y.Wong \& P.C.Boyce, Galantharum kishii P.C.Boyce \& S.Y.Wong, Gamogyne bella (S.Y.Wong \& P.C.Boyce) S.Y.Wong \& P.C.Boyce, Hera hebe (S.Y.Wong, S.L.Low \& P.C.Boyce) S.Y.Wong \& P.C.Boyce, Piptospatha insignis N.E.Br., four of the five described species of Pursegloveia S.Y.Wong, S.L.Low \& P.C.Boyce, Schottarum sarikeense (Bogner \& M.Hotta) P.C.Boyce \& S.Y.Wong, Schottariella mirifica P.C.Boyce \& S.Y.Wong, all six described species of Toga S.Y.Wong, S.L.Low \& P.C.Boyce, and so on - and yet they are absent from seemingly ecologically identical localities a few kilometres (in extreme examples a few tens of metres) distant. Additionally, enigmas abound, as with Fenestratarum P.C.Boyce \& S.Y.Wong, where the two described species occur, each restricted to a single location, $600 \mathrm{~km}$ apart and on entirely different geologies (Cretaceous sandstones and Neogene basalt).

\section{River basins}

When plants are closely associated with rivers and streams it is reasonable to consider the possibility that species and species group distributions will be linked to river basins. The only pollen-flow paper ever published for Asian rheophytic aroids (Mori \& Okada, 2001) presents reliable evidence that pollen flow is restricted within a localised population of a rheophytic species (in this instance Sumatran Furtadoa sumatrensis M.Hotta) with the result that different populations in adjacent river systems remain genetically distinct. This situation provides some substance to the possibility that the conditions to drive multiple speciation (in this instance localised in-breeding) are in place. The problem on Borneo is that none of the distributions of multi-species genera accord convincingly with river basins, and even the few species with extensive enough distributions to be usefully considered as candidates for river basin pattern distribution do not stand close scrutiny. For example Phymatarum borneense M.Hotta, the sole species of its genus, is a common and locally abundant species along a considerable area of the north coast of Borneo, from the Tatau basin of central north Sarawak to the extremity of the south west of Sabah, on the way extending through more than a dozen river basins, 11 alone in Sarawak (Fig. 1). Another example might be Ooia havilandii (Engl.) S.Y.Wong \& P.C.Boyce: it is the only Ooia S.Y.Wong \& P.C.Boyce species occurring in the enormous Rejang Basin but is replaced in the western part of the basin with Ooia secta S.Y.Wong \& P.C.Boyce, which extends through the Song, Sarikei, Kanowit and Skraang river valleys leaving one wondering whether the Rejang basin western boundary might not be an artefact of cartographers' imprecision. This possibility is further reinforced by Schottarum P.C.Boyce \& S.Y.Wong and (admittedly monospecific) Schottariella P.C.Boyce \& S.Y.Wong (Fig. 1), which present evidence 
that the current accepted western boundary of the Rejang basin with its continuity with the Kanowit and Song river valleys and into the Krian, Saribas and Lupar basins does not at all reflect the mesophyte and rheophyte biogeography of the region (Low et al., 2011).

Other examples of widespread species that fail to remain in a single basin are Rhaphidophora typha P.C.Boyce and $R$. beccarii, with the second extending throughout western Sunda as far east as the Lupar Divide, after which it is replaced with $R$. typha until Brunei, and thereafter $R$. fluminea Ridl., the last named being a point endemic at Bongaya (Tongkul, 1991).

\section{Geology}

Borneo has one of the most complex surface geologies of anywhere in tropical Asia (Tate, 2001) and, not unexpectedly, the importance of interpreting geology in understanding the distribution of rheophytic species (indeed any plant species) cannot be over-emphasised. Only a tiny handful of rheophytic aroid species are not restricted to their underlying geology, and geological obligations are often expressed in remarkably subtle ways. To take three examples for Borneo, in west Sarawak Heteroaridarum borneense M.Hotta and H. nicolsonii (Bogner) S.Y.Wong \& P.C.Boyce occur in the lowlands, on Paleogene and Neogene sandstones, while H. crassum (S.Y.Wong \& P.C.Boyce) S.Y.Wong \& P.C.Boyce occurs on Eocene sandstones between 400-800 m. Unlike the two lowland species Heteroaridarum crassum is better adapted to drier conditions with sub-succulent leaf blades notable for their much-thickened shiny waxy adaxial cuticle. Also in north west Borneo three species of Rhynchopyle Engl. [R. elongata (Engl.) Engl., R. impolita (S.Y.Wong, P.C.Boyce \& Bogner) S.Y.Wong $\&$ P.C.Boyce, and $R$. viridistigma (S.Y.Wong, P.C.Boyce \& Bogner) S.Y.Wong \& P.C.Boyce] are, within a distance of under $35 \mathrm{~km}$, respectively restricted to granite, coastal sandstones, and Karst or basalt. Meanwhile in north eastern Borneo the recently described Bucephalandra danumensis S.Y.Wong,P.C.Boyce \& Kartini is very narrowly restricted to igneous stream beds and waterfalls outcropping through Cretaceous deepwater sediments.

Mulu furnishes fine examples of localised rheophytic distributions associated with intersecting or proximal differing geologies: Bucephalandra muluensis (M.Hotta) S.Y.Wong \& P.C.Boyce, a Mulu endemic, is restricted to lowland karstic riverine rocks; B. oblanceolata (M.Hotta) S.Y.Wong \& P.C.Boyce from adjacent Setap shales reoccurs in Brunei on the same shale formation wherever it resurfaces; Burttianthus purseglovei (Furtado) S.Y.Wong \& P.C.Boyce, another shale-restricted species, although seemingly not as exactingly so as B. oblanceolata, occurs westwards on any exposed shales as far as the Ulu Mayeng, Tau range, Bintulu. Another shale-dependent species at Mulu, often occurring mixed with the two foregoing is Gamogyne burbidgei N.E.Br., originally described from Bukit Pagon. Finally Burttianthus hansenii (Bogner) S.Y.Wong \& P.C.Boyce (yet another Mulu endemic) from sandstones above $1350 \mathrm{~m}$, adds an altitudinal dimension in that it is sister to a lowland shale-restricted species [B. caulescens (M.Hotta) S.Y.Wong \& P.C.Boyce] that is absent from Mulu, and to a lowland coastal sandstone species $[$ B. velutandrus (S.Y.Wong, S.L.Low \& 


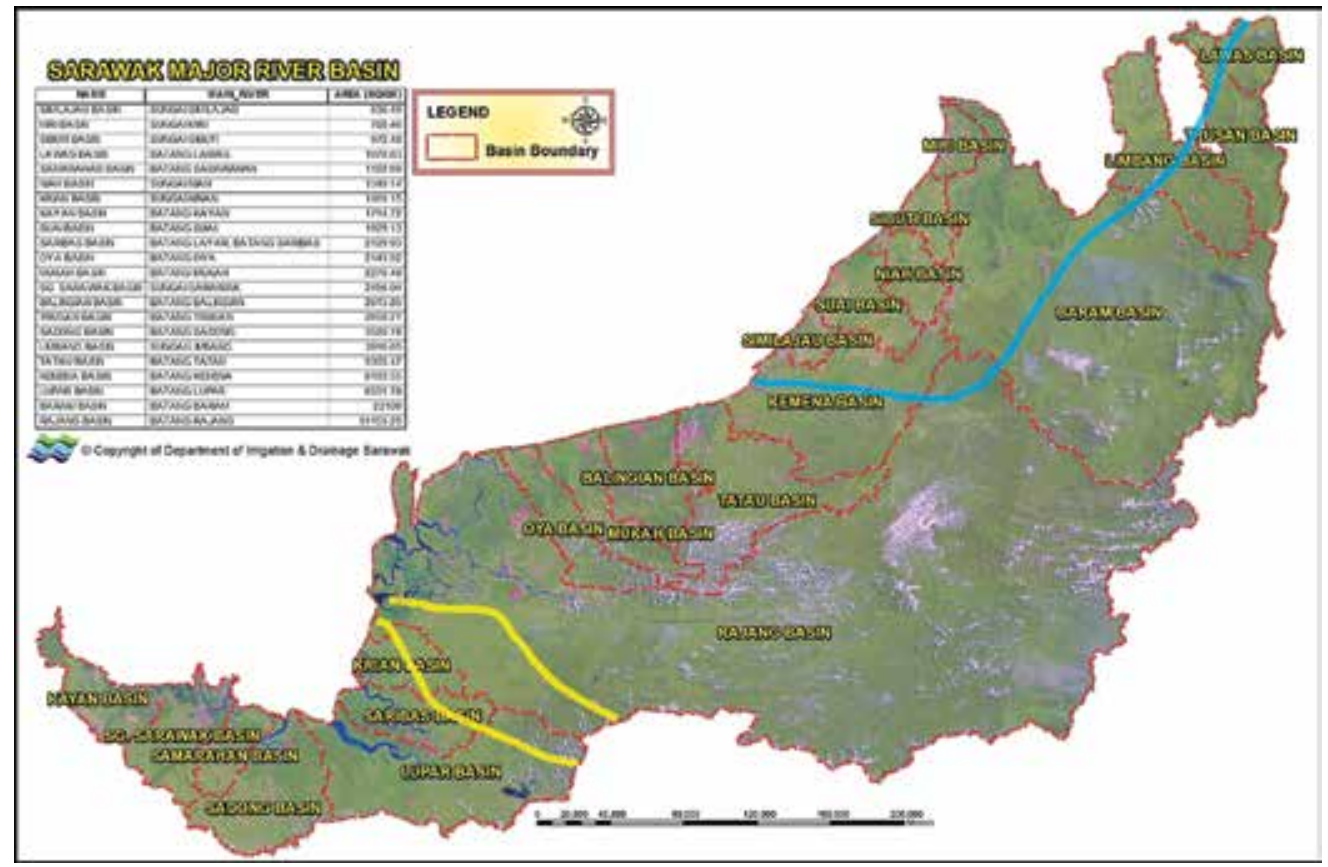

Fig. 1. River basins of Sarawak. The area between the yellow lines marks the distribution of Schottarum and Schottariella along the Kanowit (to the west) and Song (to the east) river valleys, disputing evidence of the phytogeographical western boundary of the Rejang basin with its continuity Krian, Saribas and Lupar. Blue line is the Sarawak distribution of Phymatarum crossing 11 river basins. Base image used with permission.

P.C.Boyce) S.Y.Wong \& P.C.Boyce] from Semilajau NP, and additionally overlaps with the westerly most extension of the range of B. purseglovei.

Rheophytic aroids are poorly represented on ultramafic rocks, although in eastern Sabah the monospecific genus, Tawaia S.Y.Wong \& P.C.Boyce, and one species of Bucephalandra (B. ultramafica S.Y.Wong \& P.C.Boyce) are restricted to serpentine. While most of the exposed ultramafics are in Sabah, where the more seasonal climate may well be a factor in the overall less rich aroid flora as compared with the remainder of Borneo, Sabah remains one of the least well explored parts of northern Borneo, and it is equally likely that the seeming paucity may well be at least in part an artefact, as suggested by perusal of herbarium specimens in SAN which seemed to include at least two further ultramafic-associated species, sadly inadequately preserved to permit naming.

Including Bucephalandra muluensis, just four limestone-favouring (or at least alkaline geology) rheophytic aroids are known. Two of these, Bucephalandra bogneri S.Y.Wong \& P.C.Boyce and Rhynchopyle viridistigma (S.Y.Wong, P.C.Boyce \& Bogner) S.Y.Wong \& P.C.Boyce, are from western Sarawak where they were described from Jurassic Karst limestone but have been found subsequently to occur also on Triassic basalts. The third is Ooia manduensis (A.Hay \& Bogner) S.Y.Wong 
\& P.C.Boyce, restricted to travertine streams where it is frequently found with the creeping and rooting stems coated with a layer of deposited calcite (Boyce \& Wong, 2013b). It is the only Ooia species yet found that does not produce plantlets from its roots.

By contrast to the above series of examples of species restricted to particular geology, it is striking that Rhaphidophora beccari, $R$. typha, the aforementioned Phymatarum borneense, Ooia havilandii, and Schismatoglottis ahmadii A.Hay are the most wide-ranging aroid rheophytes, and all occur on physically diverse alluvial mud and sand-banks with only $S$. ahmadii occasionally occurring on rocks, but highly unselective as to geology and, indeed, altitude (see below under v. Heterodox rheophytes). At Mulu, Phymatarum occurs almost to the exclusion of all other riverine aroids, competing with the equally aggressive Rhaphidophora typha, the latter gaining advantage when the banks become too steep for the Phymatarum to thrive and favour the flagellate shoots and the ability of regressing to the juvenile shingle stage that $R$. typha appears to employ to deal with adverse conditions. Ooia havilandii is almost exclusively associated with alluvial muddy sandbanks throughout the Rejang basin and is succeeded by $O$. secta S.Y.Wong \& P.C.Boyce, a species preferring rocky riversides in the western part of the Rejang and in the Lupar basin.

\section{Subcategories of rheophyte}

Van Steenis (1981: 29 et seq., and somewhat modified 1987: 269) divided rheophytes into three main groups:

1. Hydrophytic rheophytes - flaccid, permanently submerged aquatic herbs with usually floating, often strap-shaped, leaves.

2. Torrenticolous rheophytes - plants with vegetative parts permanently submerged in turbulent water and producing fertile emerged aerial parts during which time submerged parts decay.

3. Rheophytic landplants - plants wholly or partially submerged only when rivers are in spate.

All obligate rheophytic aroids belong to the third group. Neotropical Jasarum G.S.Bunting (Bunting, 1975; Bogner, 1985) and the majority of Cryptocoryne Fisch. ex Wydler (see Othman et al., 2009 for an overview) fall largely into "Hydrophytic rheophytes", and for the purposes of this paper we are excluding them as obligate rheophytes, utilising the orthodoxy current in Araceae of referring to Jasarum and most Cryptocoryne as aquatics. On Borneo, while a few species of Cryptocoryne (e.g., C. ciliata Fisch. ex Schott and C. lingua Engl.) are helophytic, most species would be classified as "Hydrophytic rheophytes", although a few species such as C. auriculata Engl., and $C$. regina Wongso \& Ipor might qualify as a subcategory of "Rheophytic landplants" although detailed observational data are lacking (but see Jacobsen, 1985, and Wongso et al., 2017). 
In contrast to Borneo, continental tropical Asia often has distinct dry and wet seasons, and a number of Cryptocoryne species become emergent during the dry period - e.g. the Mekong (Idei et al., 2017), while the several varieties of the narrow leaved Cryptocoryne crispatula Engl., qualify as rheophytes, with some growing in rocky places along or within the river with these plants producing partly different leaf types: terete-bladed and typical foliage leaves dependent on whether submerged or emerged. In Sri Lanka there are several Cryptocoryne species which qualify as "Rheophytic landplants", e.g. C. beckettii Trimen, C. parva de Wit, and C. walkeri Schott from the central highlands, C. alba de Wit, C. bogneri Rataj, and C. thwaitesii Schott from the wet forests of the south west (Jacobsen, 1987).

Van Steenis' category "Rheophytic landplants" not unexpectedly embraces a considerable range of adaptive combinations of morphology. Indeed, in many ways the group is a catch-all for species which do not fall into the other two much more tightly-defined groups, and as such utilising "Rheophytic landplants" in discussion of the aroids is unsatisfactory. This has lead us to defining subcategories of rheophytic adaptation based on morphological and ecological criteria.

Wong (2013), Wong \& Boyce (2013), and Low et al. (2016) presented comprehensive overviews of vegetative, floral, and fruit and seed dispersal adaptations favouring rheophytism in aroids. It is not our intention here to repeat these observations, but rather to single out examples that appear to favour particular subcategories of rheophytic aroids. Excluding facultative rheophytes - species with rheophytic morphologies which do not necessarily habitually or even ever occur in the rheophytic ecological zone (examples of facultatively rheophytic Bornean aroids are Colobogynium tecturatum Schott, Schismatoglottis mayoana Bogner \& M.Hotta, S. pudenda A.Hay, among numerous others) - it is possible to discern five subcategories of rheophytes. Appendix 1 provides a complete list of Bornean obligate and facultative rheophytic aroid species, with the subcategory indicated, where known with some degree of confidence.

\section{i. Steenisian rheophytes (Fig. 2, 3)}

Steenisian rheophytic aroids are those which are intermittently and for short periods inundated by fast-moving water and exposed to waterless conditions, but only very exceptionally are then for protracted periods totally inundated or totally exposed. Although published observations, by which we mean observations based on populations over multiple contiguous seasons, are non-existent, over the last 12 years our work has persuaded us that the majority of the Bornean rheophytic aroids are broadly Steenisian rheophytes, although given the diversity not unexpectedly there are subsets of species' adaptations to consider.

In the simplest form (we use the term 'simplest' intentionally in a non-scientific, i.e. 'untested' sense, and in no way intend this to mean that group of species is any less morphologically suited to the habitat than those that follow), species such as Schismatoglottis multiflora Ridl., most Rhynchopyle species etc., may be considered archetypal rheophytic aroids, with narrowly lanceolate to elliptic leaf blades carried on flexible petioles, a free-ligular sheath, short stems, and very extensive and clinging root systems, and nodding blooms. 
One species, Schismatoglottis roseospatha Bogner, has been found to consistently occur in two distinct growth phases, the juveniles with submerged softtextured membranous leaf blades on short petioles forming dense patches with leaves floating in the current, and an emersed adult phase with thin but tough leaf blades on long petioles. The occurrence of different shape, texture, and arrangement of leaves in juvenile and adult rheophytes was noted by van Slooten (1928) who referred to such plants as paedorheophytes.

In the genus Bucephalandra exposure to regular violent spate can produce remarkable differences in vegetative appearance within a single population of a species, with the spate-subjected plants forming close-appressed mats of foliage while plants in the portions of the population not so subjected become much larger and lusher. Interestingly both morphs are capable of flowering, with the dwarfed plants and lush plants producing blooms proportionally in keeping with the plants' stature (Wong et al., 2018).

Duality of leaf shape is matched to a certain degree in Rhaphidophora beccarii and $R$. typha (and likely also $R$. fluminea but not yet observed) in that juvenile plants have a shingling habit with the leaf blades closely-space and often with the distal portion of the preceding leaf blade obscuring the base of the newer leaf. Since the nonrheophytic species to which these three Rhaphidophora are most closely similar (and thus most likely related) are also shingling as juveniles it is perhaps unlikely that the shingling habit of the rheophytic species was a homoplasious adaptive event favouring rheophytism.

A distinctive subset of species are noteworthy for very narrowly linear to remarkably filiform leafblades on very short petioles and seemingly adapted to growing in locations with extremely active and violent flood spates wherein the flexible filiform leaf blades provide a marked advantage. To date we have identified three species with this morphology: Aridarum montanum Ridl., Bucephalandra filiformis S.Y.Wong \& P.C.Boyce, and Fenestratarum culum P.C.Boyce \& S.Y.Wong.

Three genera, Phymatarum, Gosong S.Y.Wong \& P.C.Boyce and Schottariella (Fig. 4) appear to have become specialists in colonising consolidated sand and bud banks, or shingle spits, by means of deep-reaching stout tap-roots; Phymatarum further has extensive creeping-decumbent stems by which it can dominate entire stretches of river bank.

\section{ii. Xerorheophytes (Fig. 5)}

Xerorheophytes are species equally as well adapted to drought and heat as they are to sudden turbulent water. Plants of this category usually occur on bare rock, frequently in sites exposed to full sun for all of part of the day and can withstand extended periods without water flow. The plants are notable for their thickened, leathery, or succulent stiff leaf blades and proportionately very extensive root systems. Xerorheophytes include Aridarum incavatum H.Okada \& Y.Mori, Bakoa lucens, Burttianthus velutandrus, Heteroaridarum crassum and Piptospatha insignis. 


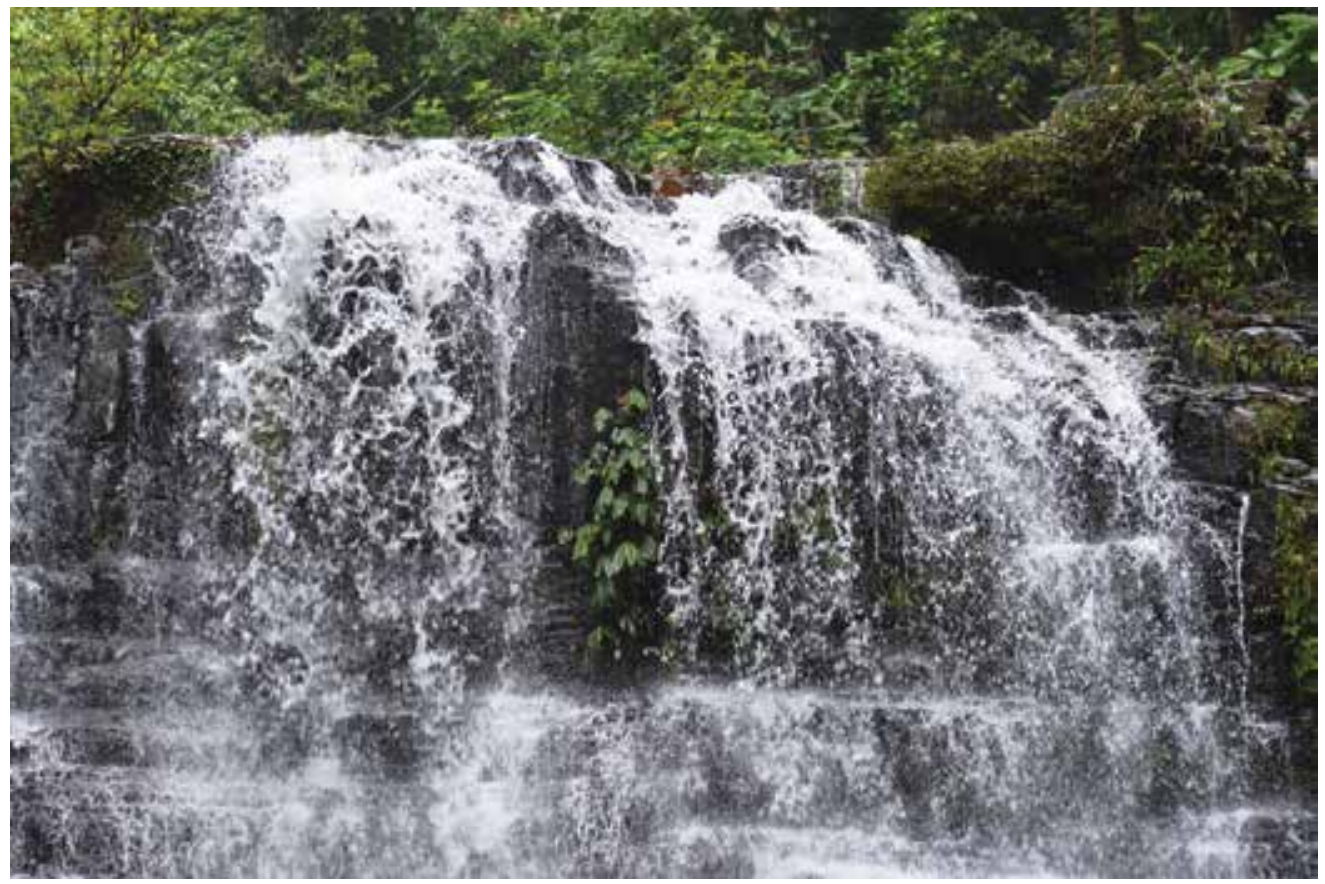

Fig. 2. Steenisian rheophyte. Heteroaridarum borneense on a granite-intruded sandstone waterfall. Water flow depicted is typical for much of the year. (Photo: P.C. Boyce).

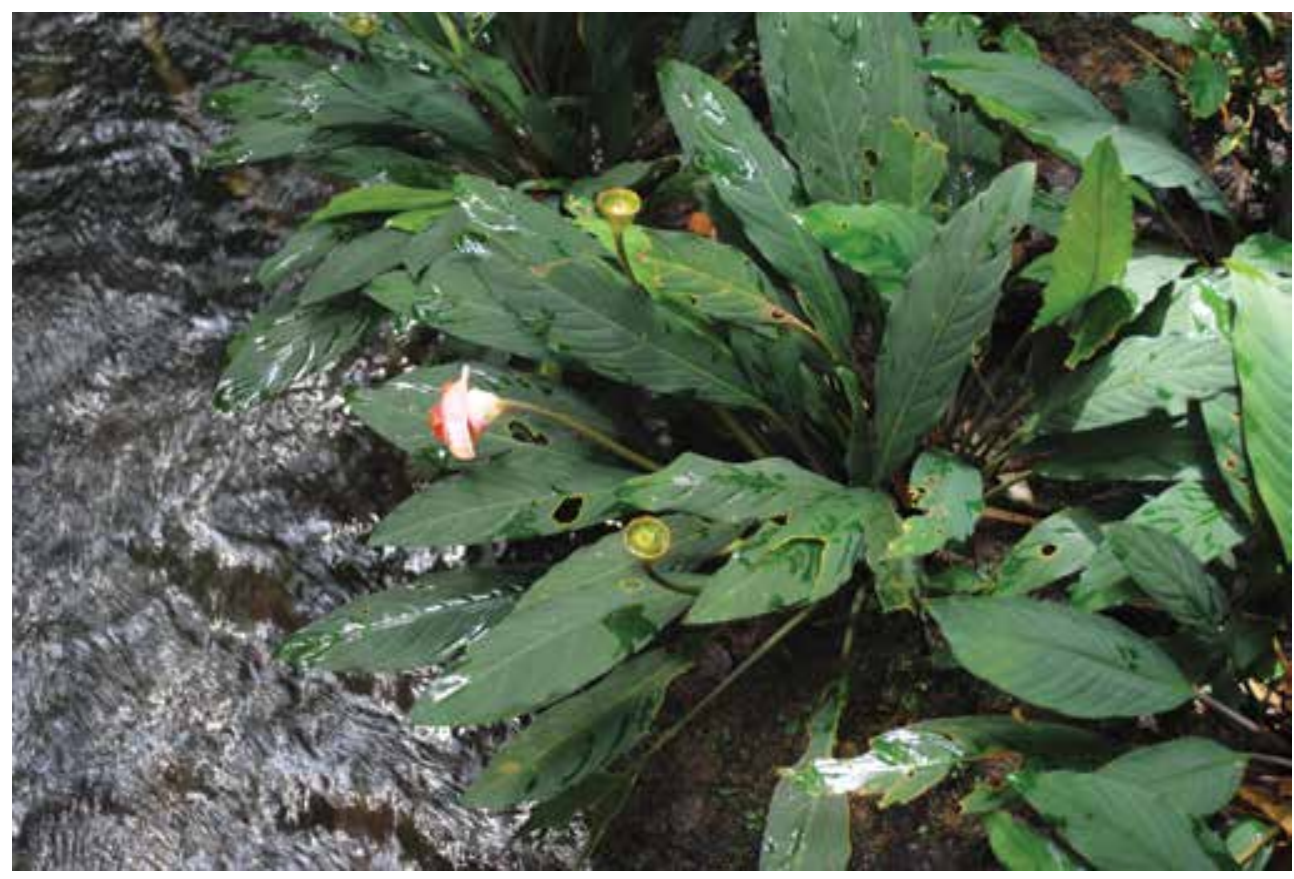

Fig. 3. Steenisian rheophyte. Rhynchopyle viridistigma at late anthesis, plants growing on basalt rocks just above average low-water level. (Photo: P.C. Boyce). 


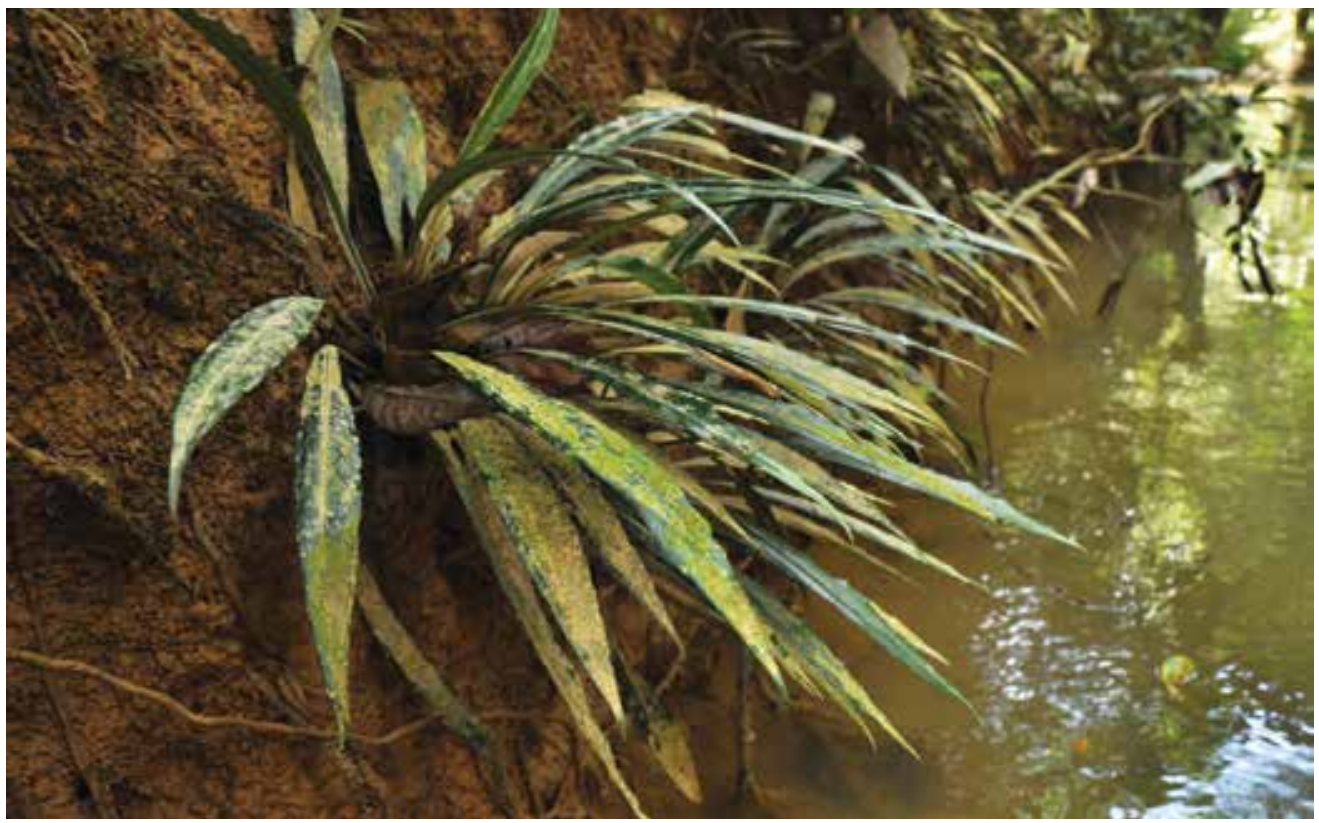

Fig. 4. Steenisian rheophyte. Schottariella mirifica population at the average daily high-water level, growing in deep alluvial mud and anchored by deep tap-roots. Note the leaf blades with copious cryptogams and silt-deposition left by receding spate high water. (Photo: P.C. Boyce).

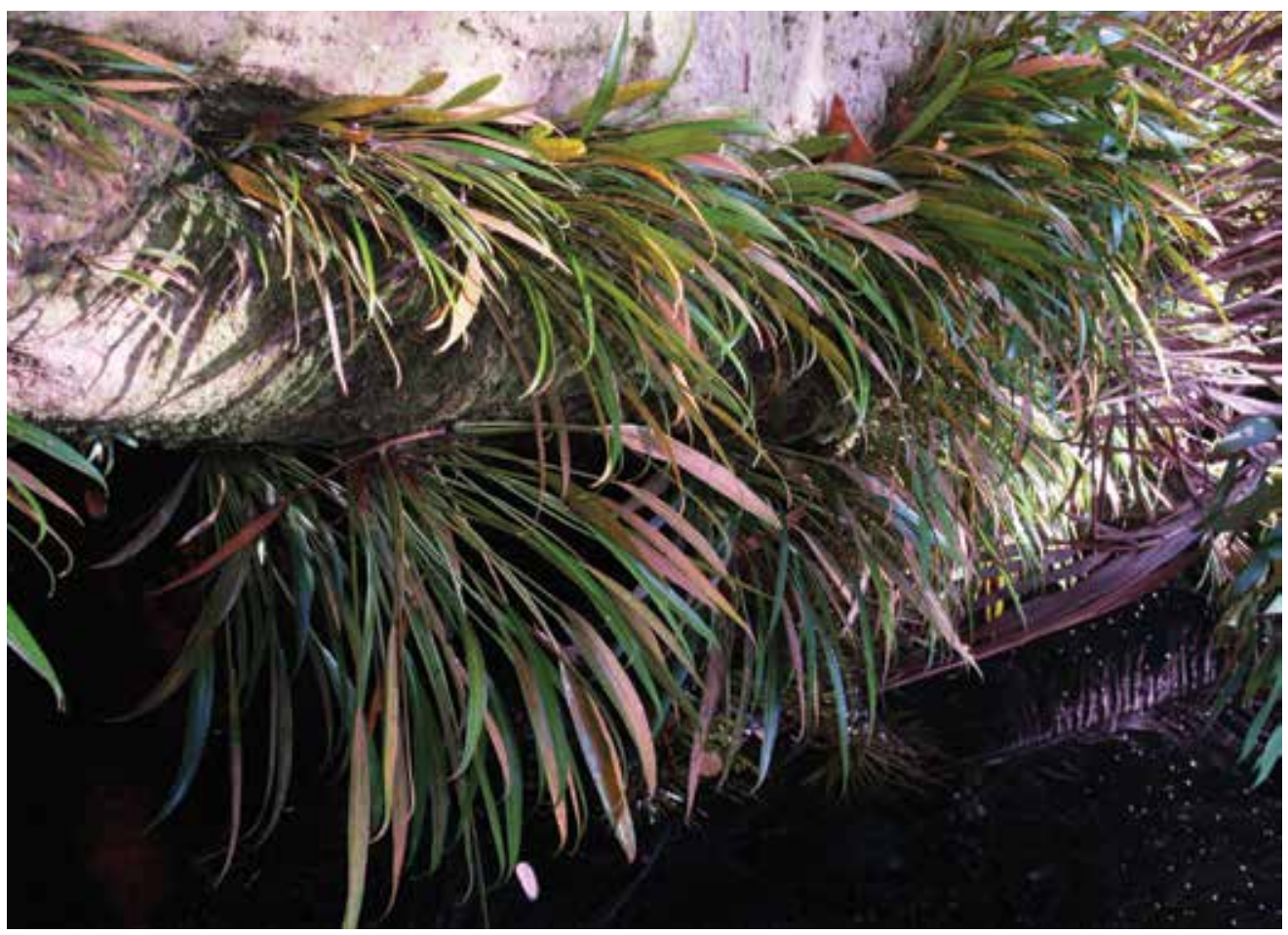

Fig. 5. Xerorheophyte. Bakoa lucens during the dry season on virtually bare sandstone. During wet weather this is a waterfall. (Photo: P.C. Boyce). 
iii. Extreme rheophytes (Fig. 6, 7)

Extreme rheophytes are species, often with pendulous leaf blades, adapted to almost constant water flow around and over the plants, with the blooms either hanging beneath the foliage, which then functions as an umbrella, or even more remarkably held above the flow on an ascending peduncle. Species included are Aridarum chamaesyce S.Y.Wong \& P.C.Boyce, Bakoaella nakamotoi (S.Y.Wong) S.Y.Wong \& P.C.Boyce, Bucephalandra belindae S.Y.Wong \& P.C.Boyce, and Ooia basalticola S.Y.Wong \& P.C.Boyce and O. paxilla S.Y.Wong \& P.C.Boyce. The last two named are exceptional in the genus in that while the blooms are nodding with the florets protected by the leathery spathe during fruit development, the peduncle straightens and stiffens to bring the persistent fruiting spathe erect (all other species of Ooia have pendulous infructescences) with the spathe orifice positioned to enable water to splash in and dislodge and wash out the decomposed fruit/seeds. Bucephalanda goliath S.Y.Wong \& P.C.Boyce and B. sordidula S.Y.Wong \& P.C.Boyce very probably belong here, but field observations are insufficient.

iv. Vegetative rheophytes (Fig. 8)

The foregoing three subcategories are based on the plant's ability to adapt to an exacting set of conditions within the rheophytic niche. We deliberately excluded from consideration the sexual reproductive attributes of the species, not to imply that the adaptation to the subcategory is reproduction-independent - that would be patently absurd - but rather that the holism of the individual species fits the environment to which it is best-suited, and in the case of the xerorheophytes to which it is absolutely restricted. In any case in most instances our understanding of reproduction remains far too patchy to be confident to use it in defining ecological subgroups. The criteria for defining Vegetative rheophytes are, however, somewhat different in that they display clear asexual reproductive adaptations which field-observations support as being very highly advantageous. All species of Ooia except $O$. manduensis, and all species of Gamogyne and Hottarum Bogner \& Nicolson produce copious plantlets from the exposed roots and by this means often dominate the area in which they occur. Species of Ooia have comparatively massive roots with an unusual gel cap covering the active root tip and extending one or two cm backwards along the root. The cap appears to function to maintain root-tip moisture in much the same manner as does the root cap occurring at the tip of the long, often free-hanging feeder roots, produced by species of Monstereae. Most Ooia species (but see iii. Extreme rheophytes above) have infructescences pendulous by means of a drooping peduncle, with the fruits enclosed inside a broadly fusiform persistent spathe with a somewhat restricted terminal entrance, and with turbulence-dispersed seeds (Wong \& Boyce, 2016b). Gamogyne bella (S.Y.Wong \& P.C. Boyce) S.Y.Wong \& P.C.Boyce is an additional oddity by occurring solely on consolidated mud in slow moving streams where it forms extensive carpets that are inundated by to up to one meter turbid water for up to two weeks at a time in the wet season (Wong \& Boyce, 2016c). A similar situation is found in Philippines Schismatoglottis prietoi P.C.Boyce et al. in which the carpets are formed by extensive slender stolons (Boyce et al., 2015). Several obligate rheophytic 
Schismatoglottis produce adventitious plantlets from specialised points on the leaf blade (Schismatoglottis bulbifera H.Okada et al.), or from abraded and torn leaf blades (S. heterodoxa S.Y.Wong, S. petradoxa S.Y.Wong \& P.C.Boyce).

\section{v. Heterodox rheophytes (Fig. 9)}

One obligate rheophyte, Schismatoglottis ahmadii has every appearance of having have adapted to the ecology with, aside some toughening of the leaf blades and strengthening of the root system discernible in individuals in more exposed situations, almost no outwardly obvious vegetative alterations so typical of rheophytic Schismatoglottideae, such as largely free ligular sheathes (Wong, 2013), and by producing blooms and fruits that have no discernible functional difference to that of the mesophytic species group to which it is allied - the Calyptrata clade (Wong et al., 2016; Hoe et al., 2018). A further peculiarity of Schismatoglottis ahmadii is that it is widespread, occurring from east of the Batang Balleh in central Sarawak to east Sabah, and shows a remarkable altitudinal range, from $50 \mathrm{~m}$ at Mulu to over $1500 \mathrm{~m}$ on Kinabalu. Only one other rheophytic aroid, Ooia glans S.Y.Wong \& P.C.Boyce, has an almost comparable altitudinal range (60-950 $\mathrm{m}$ in Kuching Division, Sarawak).

\section{Conclusions}

With the genus Cryptocoryne, treated as rheophytic by van Steenis (1981, 1987), but treated here as aquatic or helophytic on Borneo with the qualifications noted above excluded all known aroid rheophytes on Borneo (and elsewhere as far as is known) belong to van Steenis's "Rheophytic landplants" group, a highly heterogeneous collection which blurs highly distinctive morphological and ecological differences in the aroids. Subdividing the aroids into five subcategories of rheophyte is a useful first step towards demarcating groups of taxa for more focused study, in particular the stilldiverse Steenisian rheophytes wherein there are probable further subcategories that could be separated out with improved understanding. None of our newly proposed subcategories are intended as definitive. Rather they are aimed at promoting field observations by better enabling descriptive analyses much in the same manner as does Hallé et al. (1978) for trees, and at defining manageable sets of taxa to promote more detailed study of species occurring in a particular rheophytic niche. The Xerorheophytes in particular cry-out for an in-depth study on how they succeed with what is unquestionably one of the most ill-favoured habitats in the humid tropics.

ACKNOWLEDGEMENTS. We are indebted to Alistair Hay (NSW) for numerous suggestions that much-improved an earlier draft of the manuscript. Likewise we are grateful to Niels Jacobsen (C) for comments on and corrections to the Cryptocoryne discussion. Lastly we extend our thanks to two anonymous referees for useful comments. 


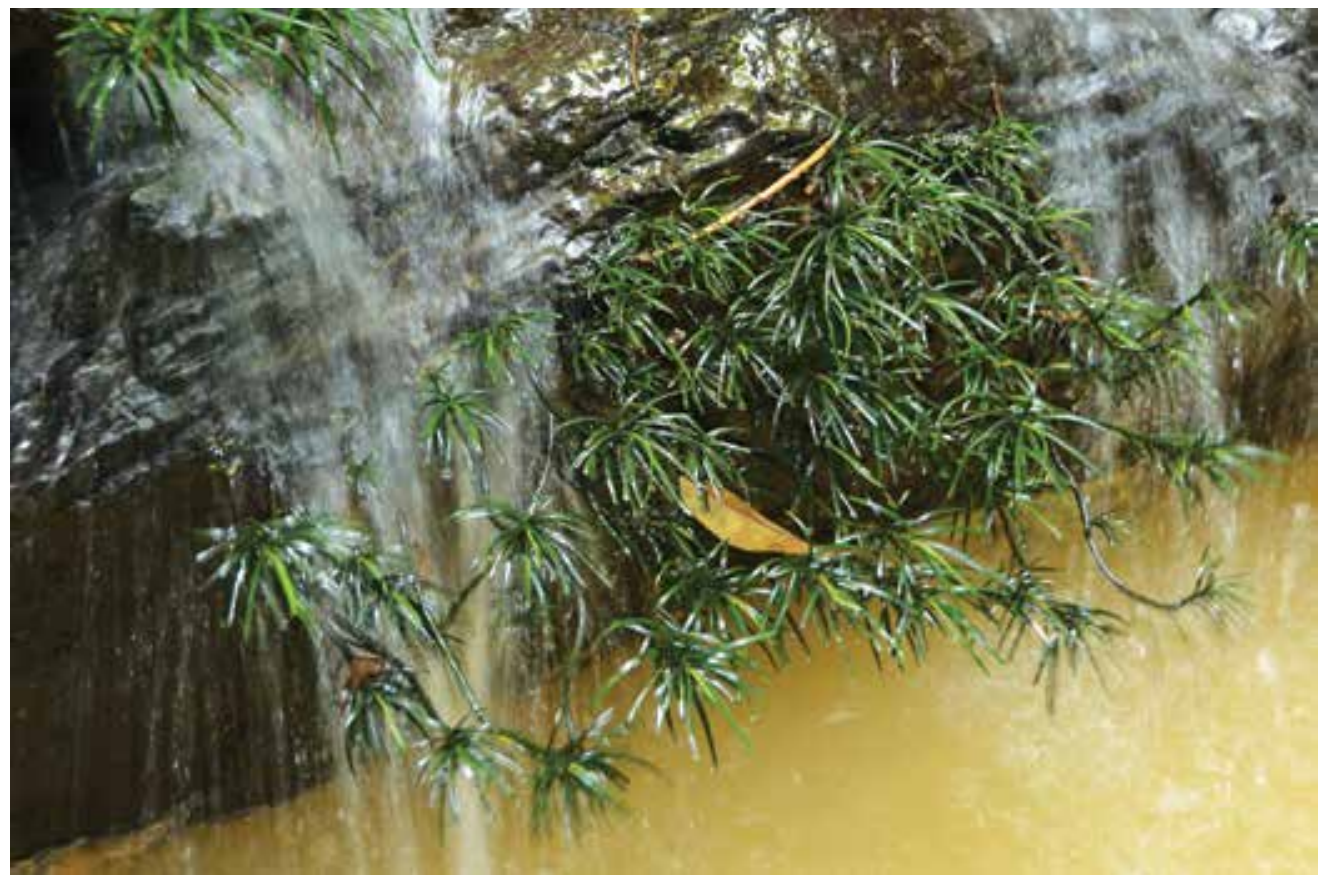

Fig. 6. Extreme rheophyte. Aridarum chamaesyce on a shale cascade. Photograph taken during dry season. (Photo: P.C. Boyce).

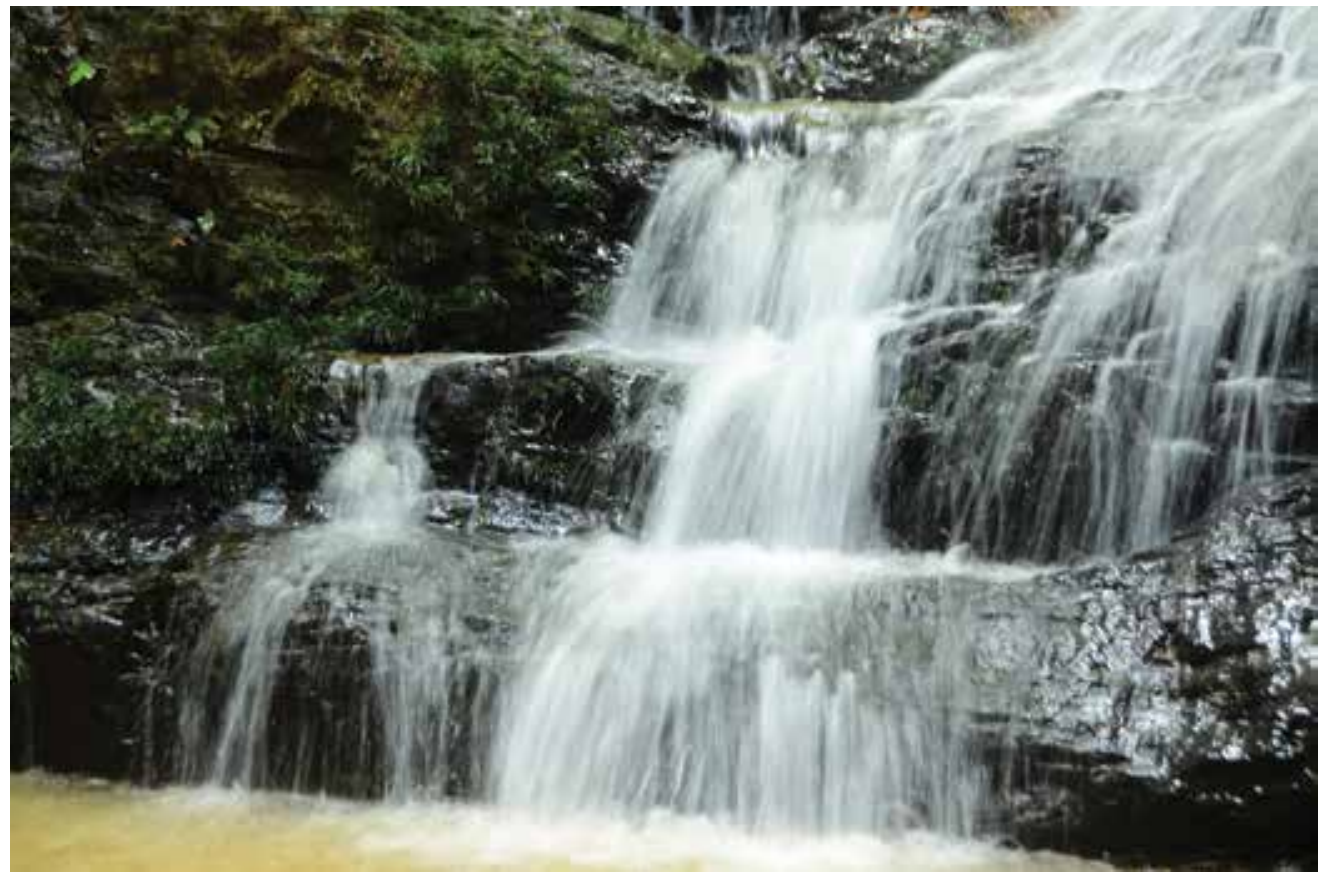

Fig. 7. Extreme rheophyte. Habitat of Aridarum chamaesyce on a shale cascade. Photograph taken during dry season. (Photo: P.C. Boyce). 


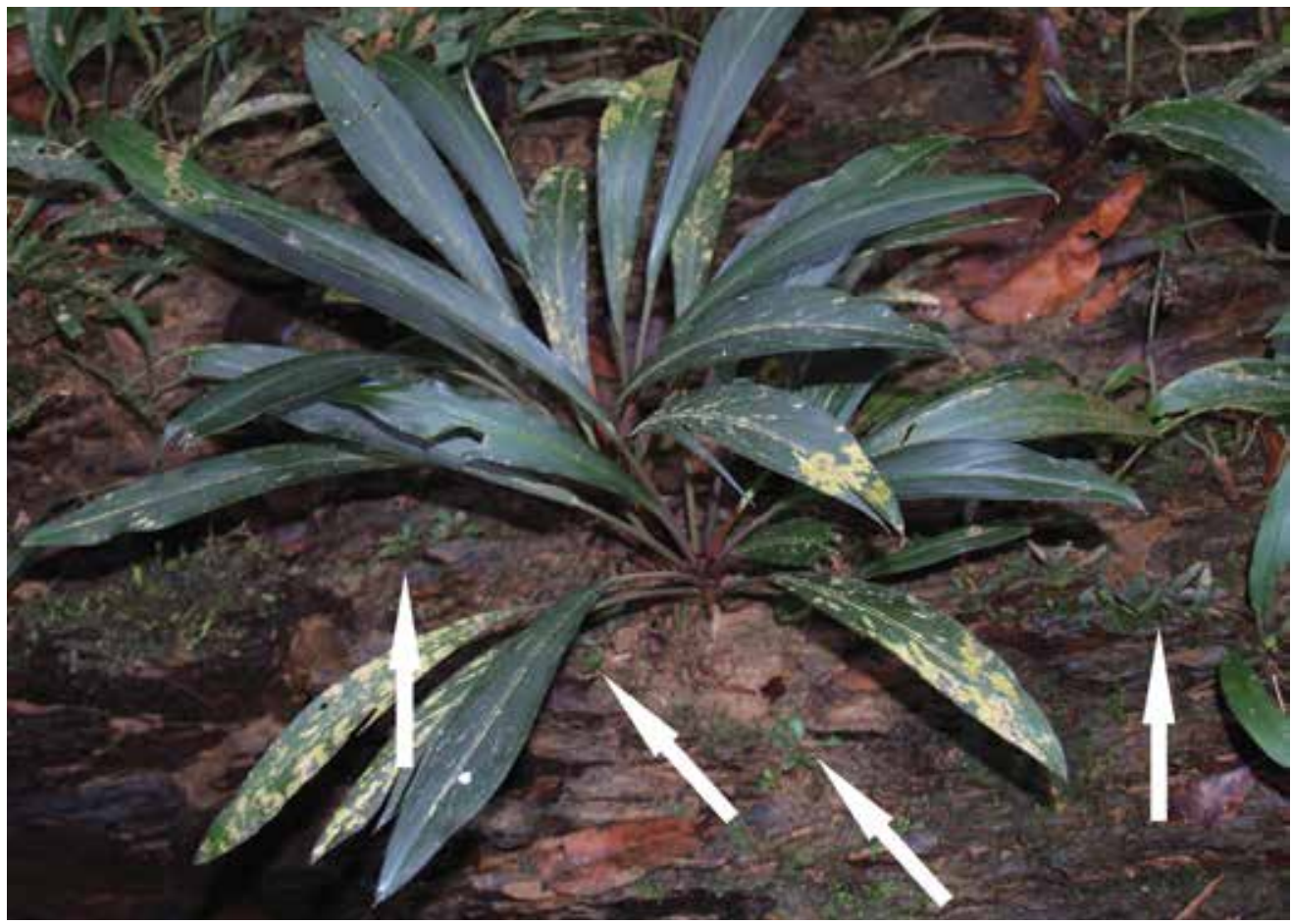

Fig. 8. Vegetative rheophyte. Gamogyne burbidgei on Setap shales, with adventitious plants arising from roots indicated by white arrows. (Photo: P.C. Boyce).

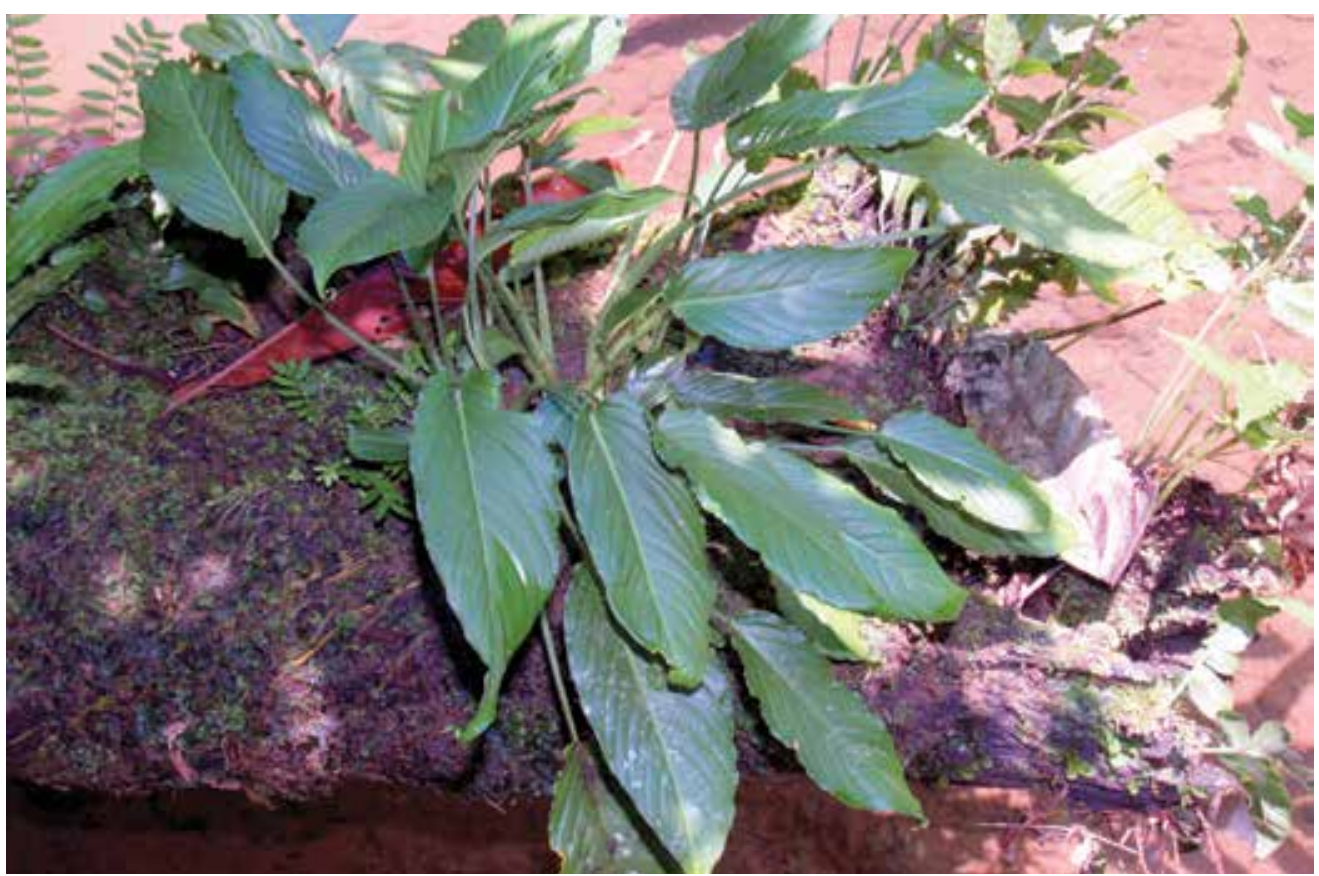

Fig. 9. Heterodox rheophyte. Schismatoglottis ahmadii on coarse-grained sandstone photographed during dry weather; in stormy weather the plants are submerged by up to $1 \mathrm{~m}$ of fast-moving water. (Photo: P.C. Boyce). 


\section{References}

Amrhein, V., Greenland, S. \& McShane, B. (2019). Retire statistical significance. Nature 567: 305-307.

Beath, D.N. (1996). Pollination of Amorphophallus johnsonii (Araceae) by carrion beetles (Phaeochrous amplus) in a Ghanaian rain forest. J. Trop. Ecol. 12: 409-418.

Beath, D.N. (1999). Dynastine scarab beetle pollination in Dieffenbachia longispatha (Araceae) on Barro Colorado Island (Panama) compared with La Selva Biological Station (Costa Rica). Aroideana 22: 63-71.

Beccari, O. (1902). Nelle foreste di Borneo. Firenze: S. Landi.

Beccari, O. (1904). Wanderings in the great forests of Borneo. London: A. Constable \& Co.

Bogner, J. (1985). Jasarum steyermarkii Bunting, an aquatic aroid from Guyana highland. Aroideana 8: 55-63.

Bogner, J. \& Hay, A. (2000). Schismatoglottideae (Araceae) in Malesia 2: Aridarum, Bucephalandra, Phymatarum and Piptospatha. Telopea 9: 179-222.

Boyce, P.C. \& Croat, T.B. (2011 onwards). The Überlist of Araceae, Totals for Published and Estimated Number of Species in Aroid Genera. Electronic resource. http://www.aroid. org/genera/180211uberlist.pdf. Accessed 3 Mar. 2019.

Boyce, P.C. \& Wong S.Y. (2007). Studies on Schismatoglottideae (Araceae) of Borneo IV: Preliminary observations of spathe senescence mechanics in Schismatoglottis Zoll. \& Moritzi, in Sarawak, Malaysian Borneo. Aroideana 30: 56-70.

Boyce, P.C. \& Wong S.Y. (2012). Studies on Schismatoglottideae (Araceae) of Borneo XX: Beccari's 'La Più piccola delle Aracee' (Microcasia pygmaea) recollected and transferred to Bucephalandra Schott. Webbia 67(2): 139-146

Boyce, P.C. \& Wong S.Y. (2013a). Studies on Schismatoglottideae (Araceae) of Borneo XXVII - New species of Aridarum, and notes on the Aridarum Rostratum Complex. Willdenowia 43: 91-99.

Boyce, P.C. \& Wong, S.Y. (2013b). Studies on Schismatoglottideae (Araceae) of Borneo XXIX - Piptospatha manduensis — the ultimate aroid calciphile? Aroideana 36: 98-103.

Boyce, P.C. \& Wong S.Y. (2014). Studies on Schismatoglottideae (Araceae) of Borneo XXXXI: Additional new species of Bucephalandra. Willdenowia 44: 415-421.

Boyce, P.C., Medecilo, M.P. \& Wong S.Y. (2015). A new and remarkable aquatic species of Schismatoglottis (Araceae) from the Philippines. Willdenowia 45(3): 405-408.

Bunting, G.S. (1975). Nuevas especies para la revisión de las Araceas. Acta Bot. Venez. 10(14): $263-335$.

Dakkus, P.M.W. (1925). Naar den Boekit Raja in Centraal-Borneo. Trop. Natuur 14(9): 129139.

Dressler, R.L. (1968). Pollination by euglossine bees. Evolution 22(1): 202-210.

Endert, F.H. (1927). Midden-Oost-Borneo Expeditie 1925: botanisch en floristisch verslag. Batavia [Jakarta]: G. Kolff \& Co.

Hallé, F., Oldeman, R.A.A. \& Tomlinson, P.B. (1978). Tropical trees and forests - an architectural analysis. Berlin, Heidelberg, New York: Springer-Verlag.

Hay, A. (1990). Aroids of Papua New Guinea. Madang: Christensen Research Institute.

Hay, A. (1999). Revision of Homalomena (Araceae - Homalomeneae) in New Guinea, the Bismarck Archipelago and Solomon Islands. Blumea 44: 41-71.

Hay, A. \& Yuzammi (2000). Schismatoglottideae (Araceae) in Malesia I: Schismatoglottis. Telopea 9: 1-177. 
Hoe, Y.C., Gibernau, M. \& Wong, S.Y. (2018). Diversity of pollination ecology in the Schismatoglottis calyptrata complex clade (Araceae). Pl. Biol. (Stuttgart) 20(3): 563578.

Idei, T., Bastmeijer, J.D. \& Jacobsen, N. (2017). Stories from the Mekong, part 2: The Cryptocoryne (Araceae) habitats in the Chiang Khan district, Loei province, Thailand. Thai Forest Bull., Bot. 45(1): 58-78.

Jacobsen, N. (1985). The Cryptocoryne of Borneo (Araceae). Nord. J. Bot. 5: 31-50.

Jacobsen, N. (1987). 21. Cryptocoryne. In: M.D. Dassanyake \& F.R. Fosberg (eds) A revised Handbook to the Flora of Ceylon, vol. IV, pp. 85-99. New Delhi: Amerind Publishing.

Low, S.L., Wong, S.Y., Jamliah, J. \& Boyce, P.C. (2011). Phylogenetic study of the Hottarum Group (Araceae: Schismatoglottideae) by utilizing nuclear ITS region. Gard. Bull. Singapore 63(1\&2): 237-243.

Low, S.L., Wong, S.Y. \& Boyce, P.C. (2014). Schottarum (Schismatoglottideae: Araceae) substantiated based on combined nuclear and plastid DNA sequences. Pl. Syst. Evol. 300(4): 607-617.

Low, S.L., Wong, S.Y., Ooi, I.H., Hesse, H., Städler, Y., Schönenberger, J. \& Boyce, P.C. (2016). Floral diversity and pollination strategies of three rheophytic Schismatoglottideae (Araceae). Pl. Biol. (Stuttgart) 18: 84-97.

Low, S.L., Wong, S.Y. \& Boyce, P.C. (2018). Naming the chaos: generic redelimitation in Schismatoglottideae (Araceae). Webbia 72(2): 1-100.

Mori, Y. \& Okada, H. (2001). Reproductive biology and pollen flow of a rheophytic aroid, Furtadoa sumatrensis (Araceae) in the Malesian wet tropics. Pl. Syst. Evol. 227: 37-47.

Othman, A.S., Jacobsen, N. \& Mansor, M. (2009). Cryptocoryne of Peninsular Malaysia: a portrait of an enchanting plant genus. Pulau Pinang: Penerbit Universiti Sains Malaysia.

Puff, C. \& Chayamarit, K. (2011). Living under water for up to four months of the year: observations on the rheophytes of the Mekong River in the Pha Taem National Park area (Thailand/Laos border). Thai Forest Bull., Bot. 39: 173-205.

Ridley, H.N. (1890). On the method of fertilization in Bulbophyllum macranthum, and allied orchids. Ann. Bot. (Oxford) 4(3): 327-336.

Ridley, H.N. (1893). On the flora of the eastern coast of the Malay Peninsula. Trans. Linn. Soc. London, Bot. 3: 267-408.

Ridley, H.N. (1904). On the flowering of Barringtonia racemosa. J. Straits Branch Roy. Asiat. Soc. 41: 135-136.

Tate, R.B. (2001). The geology of Borneo island. CD-ROM. Kuala Lumpur: Geological Society of Malaysia/Persatuan Geologi Malaysia.

Ting A.P.J., Wong S.Y., Jamliah J. \& Boyce, P.C. (2012). Phylogenetic study of Schismatoglottis Nervosa Complex (Araceae: Schismatoglottideae). Gard. Bull. Singapore 64: 211-219.

Tongkul, F. (1991). Basin development and deposition of the Bongaya Formation in the Pitas Area, Northern Sabah. Geol. Soc. Malaysia Bull. 29: 183-193.

Van der Pijl, L. (1937). Biological and physiological observations on the inflorescence of Amorphophallus. Recueil Trav. Bot. Neerl. 34: 157-167.

Van der Pijl, L. \& Dodson, C.H. (1966). Orchid flowers: their pollination and evolution. Coral Gables: University of Miami Press.

Van Slooten, D.F. (1928). Het geslacht Dipterocarpus. Trop. Natuur 17(9): 139-149.

Van Steenis, C.G.G.J. (1932). Botanical results of a trip to the Anambas and Natoena Islands [with Notes on the vegetation of Djemadja by M.R. Henderson]. Bull. Jard. Bot. Buitenzorg, ser. 3, 12: 151-211. 
Van Steenis, C.G.G.J. (1948). Hygrophila oligosperma, sp. nov., a new rheopyte from Borneo. Bull. Jard. Bot. Buitenzorg, ser.3, 17: 398.

Van Steenis, C.G.G.J. (1952). Rheophytes. Proc. Roy. Soc. Queensland 62(6): 61-68.

Van Steenis, C.G.G.J. (1978). Rheophytes in South Africa. Bothalia 12(3): 543-546.

Van Steenis, C.G.G.J. (1981). Rheophytes of the world: an account of the flood-resistant flowering plants and ferns and the theory of autonomous evolution. Alpena aan den Rijn \& Rockville: Sijthoff \& Noordhoff.

Van Steenis, C.G.G.J. (1987). Rheophytes of the world. Supplement. Allertonia 4(5): 267-330. Wong S.Y. (2013). Rheophytism in Bornean Schismatoglottideae. Syst. Bot. 38(1): 32-45.

Wong S.Y. \& Boyce, P.C. (2007). Studies on Schismatoglottideae (Araceae) of Borneo II: Aridarum crassum, a new species from Sarawak, Malaysian Borneo. Gard. Bull. Singapore 58: 279-286.

Wong S.Y. \& Boyce, P.C. (2013). The role of the interstice staminodes of Bucephalandra Schott (Araceae: Schismatoglottideae). Newslett. Int. Aroid Soc. 35(2): 11-12.

Wong S.Y. \& Boyce, P.C. (2014). Studies on Schismatoglottideae (Araceae) of Borneo XXX - New species and combinations for Bucephalandra Schott. Willdenowia 44: 149-199.

Wong S.Y. \& Boyce, P.C. (2015). Studies on Schismatoglottideae (Araceae) of Borneo XXXXVII - Aridarum ashtonii, a new species from the Hose Mountains, and notes on Aridarum burttii. Aroideana 38E(2): 10-22.

Wong S.Y. \& Boyce, P.C. (2016a). Studies on Schismatoglottideae (Araceae) of Borneo LVII: Bucephalandra filiformis - a new species from Maligan, Sarawak, Malaysian Borneo. Aroideana 39(2): 56-60.

Wong S.Y. \& Boyce, P.C. (2016b). Studies on Schismatoglottideae (Araceae) of Borneo LI: Ooia revised, including a reconsideration of Ooia grabowskii. J. Jap. Bot. 91 (supplement): 138-167. 2016

Wong S.Y. \& Boyce, P.C. (2016c). Studies on Schismatoglottideae (Araceae) of Borneo LVIII - Further novelties described for the genus Piptospatha, and a note on Piptospatha Sect. Gamogyne. Aroideana 39(2): 61-70.

Wong S.Y. \& Boyce, P.C. (2017). Studies on Schismatoglottideae (Araceae) of Borneo LXI: Aridarum chamaesyce, a new species, and corrections to an earlier interpretation of Aridarum montanum. Aroideana 40(3): 15-26.

Wong S.Y., Boyce, P.C., Othman, A.S. \& Leaw C.P. (2010). Molecular phylogeny of tribe Schismatoglottideae based on two plastid markers and recognition of a new tribe, Philonotieae, from the Neotropics. Taxon 59(1): 117-124.

Wong S.Y., Boyce, P.C. \& Low S.L. (2012). Studies on Schismatoglottideae (Araceae) of Borneo XXIV - Two new species of Aridarum from Kalimantan, and notes on the Aridarum Burttii Complex. Willdenowia 42: 261-268.

Wong S.Y., Low S.L. \& Boyce, P.C. (2014a). Studies on Schismatoglottideae (Araceae) of Borneo XXXV - Seven New species of Aridarum. Aroideana 37: 9-32.

Wong S.Y., Low S.L. \& Boyce, P.C. (2014b). Studies on Schismatoglottideae (Araceae) of Borneo XXXXII: Additional new species of Aridarum. Aroideana 37E(2): 34-49.

Wong S.Y., Hoe Y.C. \& Boyce, P.C. (2016). Studies on Schismatoglottideae (Araceae) of Borneo LIX - A preliminary conspectus of Schismatoglottis calyptrata clade species for Sarawak. Aroideana 39(2): 71-100.

Wong S.Y., Boyce, P.C. \& Kartini Saibeh (2018). Studies on Schismatoglottideae (Araceae) of Borneo LXVII: Bucephalandra danumensis, a new species from Sabah, Malaysian Borneo. Webbia 73(2): 225-231. 
Wongso, S., Bastmeijer, J.D., Budianto, H., Ipor, I.B., Munk, K.R., Ørgaard, M. \& Jacobsen, N. (2017). Six new Cryptocoryne taxa (Araceae) from Kalimantan, Borneo. Willdenowia 47(3): 325-339.

Young, H.J. (1986). Beetle Pollination of Dieffenbachia longispatha (Araceae). Amer. J. Bot. 73(6): 931-944.

Young, H.J. (1988a). Neighborhood size in a beetle pollinated tropical aroid: effects of low density and asynchronous flowering. Oecologia 76: 461-466.

Young, H.J. (1988b). Differential importance of beetle species pollinating Dieffenbachia longispatha (Araceae). Ecology 69(3): 832-844. 
Appendix 1. List of Bornean obligate and facultative rheophytic aroid species. Subcategories: $i=$ Steenisian rheophytes; ii $=$ Xerorheophytes; ii $=$ Extreme rheophytes; iv $=$ Vegetative rheophytes; $\mathrm{v}=$ Heterodox rheophytes; F = Facultative rheophytes; (?) = following any subcategory indicates some degree of doubt; - = unknown.

Species Sub-

category

Aridarum chamaesyce S.Y.Wong \& P.C.Boyce, Aroideana 40(3): 20 (2017). $\quad$ iii

Aridarum incavatum H.Okada \& Y.Mori, Acta Phytotax. Geobot. 51: 1 (2000). ii

Aridarum montanum Ridl., J. Bot. 51: 201 (1913).

Aridarum pendek S.Y.Wong, S.L.Low \& P.C.Boyce, Aroideana 37: 21 (2014). i

Bakoa lucens (Bogner) P.C.Boyce \& S.Y.Wong, Bot. Stud. (Taipei) 49(4): 399 (2008).

Bakoaella nakamotoi (S.Y.Wong) S.Y.Wong \& P.C.Boyce, Webbia 72(2): 28 (2018). iii

Bakoaella sicula (S.Y.Wong) S.Y.Wong \& P.C.Boyce, Webbia 72(2): 28 (2018). $\quad$ i(?)

Bidayuha crassispatha S.Y.Wong \& P.C.Boyce, Webbia 72(2): 28 (2018). i

Bucephalandra akantha S.Y.Wong \& P.C.Boyce, Willdenowia 44: 151 (2014). i

Bucephalandra aurantiitheca S.Y.Wong \& P.C.Boyce, Willdenowia 44: 153 (2014). $\quad$ i

Bucephalandra belindae S.Y.Wong \& P.C.Boyce, Willdenowia 44: 155 (2014). $\quad$ iii

Bucephalandra bogneri S.Y.Wong \& P.C.Boyce, Willdenowia 44: 157 (2014). $\quad$ i

Bucephalandra catherineae P.C.Boyce, Bogner \& Mayo, Bot. Mag. 12(3): $152 \quad$ iii(?) (1995).

Bucephalandra chimaera S.Y.Wong \& P.C.Boyce, Willdenowia 44: 159 (2014). $\quad$ i

Bucephalandra chrysokoupa S.Y.Wong \& P.C.Boyce, Willdenowia 44: 161 (2014). $\quad$ i

Bucephalandra danumensis S.Y.Wong, P.C.Boyce \& Kartini, Webbia 73(2): 225 (2018).

Bucephalandra diabolica S.Y.Wong \& P.C.Boyce, Willdenowia 44: 163 (2014). $\quad$ i

Bucephalandra elliptica (Engl.) S.Y.Wong \& P.C.Boyce, Willdenowia 44: 165 (2014).

Bucephalandra filiformis S.Y.Wong \& P.C.Boyce, Aroideana 39(2): 57 (2016). i

Bucephalandra forcipula S.Y.Wong \& P.C.Boyce, Willdenowia 44: 167 (2014). $\quad$ i 
Appendix 1. Continuation.

\begin{tabular}{ll}
\hline Species & $\begin{array}{l}\text { Sub- } \\
\text { category }\end{array}$ \\
\end{tabular}

Bucephalandra gigantea Bogner, Pl. Syst. Evol. 145: 159 (1984).

Bucephalandra goliath S.Y.Wong \& P.C.Boyce, Willdenowia 44: 169 (2014). iii(?)

Bucephalandra kerangas S.Y.Wong \& P.C.Boyce, Willdenowia 44: 171 (2014). $\quad$ i

Bucephalandra kishii S.Y.Wong \& P.C.Boyce, Willdenowia 44: 173 (2014). i

Bucephalandra magnifolia H.Okada \& Y.Mori, Acta Phytotax. Geobot. 51: 4 (2000). i

Bucephalandra micrantha S.Y.Wong \& P.C.Boyce, Willdenowia 44: 415 (2014). $\quad$ i

Bucephalandra minotaur S.Y.Wong \& P.C.Boyce, Willdenowia 44: 175 (2014). $\quad$ i

Bucephalandra motleyana Schott, Gen. Aroid. t.56 (1858).

i(?)

Bucephalandra muluensis (M.Hotta) S.Y.Wong \& P.C.Boyce, Willdenowia 44: $177 \quad$ i (2014).

Bucephalandra oblanceolata (M.Hotta) S.Y.Wong \& P.C.Boyce, Willdenowia 44: i 179 (2014).

Bucephalandra oncophora S.Y.Wong \& P.C.Boyce, Willdenowia 44: 181 (2014). $\quad$ i

Bucephalandra pubes S.Y.Wong \& P.C.Boyce, Willdenowia 44: 181 (2014). i

Bucephalandra pygmaea (Becc.) S.Y.Wong \& P.C.Boyce, Webbia 67(2): 142 (2012). i

Bucephalandra sordidula S.Y.Wong \& P.C.Boyce, Willdenowia 44: 184 (2014). $\quad$ iii(?)

Bucephalandra spathulifolia Engl. ex S.Y.Wong \& P.C.Boyce, Willdenowia 44: $417 \quad$ i (2014).

Bucephalandra tetana S.Y.Wong \& P.C.Boyce, Willdenowia 44: $186(2014) . \quad$ i

Bucephalandra ultramafica S.Y.Wong \& P.C.Boyce, Willdenowia 44: 188 (2014). $\quad$ i

Bucephalandra vespula S.Y.Wong \& P.C.Boyce, Willdenowia 44: 190 (2014). $\quad$ i

Bucephalandra yengiae P.C.Boyce, Willdenowia 44: 192 (2014). i

Burttianthus caulescens (M.Hotta) S.Y.Wong \& P.C.Boyce, Webbia 72(2): $36 \quad$ i

(2018).

Burttianthus hansenii (Bogner) S.Y.Wong \& P.C.Boyce, Webbia 72(2): 37 (2018). $\quad$ i 
Appendix 1. Continuation.

$\begin{array}{ll}\text { Species } & \text { Sub- } \\ \text { category }\end{array}$

Burttianthus longipedunculatus (M.Hotta) S.Y.Wong \& P.C.Boyce, Webbia 72(2): 37 i (2018).

Burttianthus orestus (S.Y.Wong, S.L.Low \& P.C.Boyce) S.Y.Wong \& P.C.Boyce, Webbia 72(2): 37 (2018).

Burttianthus purseglovei (Furtado) S.Y.Wong \& P.C.Boyce, Webbia 72(2): $38 \quad$ i (2018).

Burttianthus spissus (S.Y.Wong, S.L.Low \& P.C.Boyce) S.Y.Wong \& P.C.Boyce, $\quad$ i Webbia 72(2): 38 (2018).

Burttianthus velutandrus (S.Y.Wong, S.L.Low \& P.C.Boyce) S.Y.Wong \&

P.C.Boyce, Webbia 72(2): 38 (2018).

Colobogynium tecturatum Schott, Oesterr. Bot. Z. 15: 34 (1865).

F

Fenestratarum culum P.C.Boyce \& S.Y.Wong, Aroideana 37E(2): 8 (2014). i

Fenestratarum mulyadii P.C.Boyce \& S.Y.Wong, Aroideana 38E(2): 5 (2015). $\quad$ i

Galantharum kishii P.C.Boyce \& S.Y.Wong, Aroideana 38E(2): 25 (2015). i

Gamogyne burbidgei N.E.Br., J. Bot. 20: 196 (1882). iv

Gamogyne bella (S.Y.Wong \& P.C.Boyce) S.Y.Wong \& P.C.Boyce, Webbia 72(2): $\quad$ iv 45 (2018).

Gamogyne colata (P.C.Boyce \& S.Y.Wong) S.Y.Wong \& P.C.Boyce, Webbia 72(2): iv 45 (2018).

Gamogyne deceptrix (P.C.Boyce \& S.Y.Wong) S.Y.Wong \& P.C.Boyce, Webbia iv 72(2): 46 (2018).

Gamogyne helix (S.Y.Wong \& P.C.Boyce) S.Y.Wong \& P.C.Boyce, Webbia 72(2): $\quad$ iv 46 (2018).

Gamogyne lurida (S.Y.Wong \& P.C.Boyce) S.Y.Wong \& P.C.Boyce, Webbia 72(2): iv 46 (2018). 
Appendix 1. Continuation.

\begin{tabular}{ll}
\hline Species & $\begin{array}{l}\text { Sub- } \\
\text { category }\end{array}$ \\
\hline
\end{tabular}

Hera hebe (S.Y.Wong, S.L.Low \& P.C.Boyce) S.Y.Wong \& P.C.Boyce, Webbia i 72(2): 49 (2018).

Heteroaridarum borneense M.Hotta, Acta Phytotax. Geobot. 27(3-4): 63 (1976). $\quad$ i

Heteroaridarum crassum (S.Y.Wong \& P.C.Boyce) S.Y.Wong \& P.C.Boyce, Webbia ii 72(2): 51 (2018).

Heteroaridarum nicolsonii (Bogner) S.Y.Wong \& P.C.Boyce, Webbia 72(2): $52 \quad$ i (2018)

Homalomena lancea Ridl., J. Straits Branch Roy. Asiat. Soc. 44: 176 (1905). $\quad$ i

Homalomena minutissima M.Hotta, Acta Phytotax. Geobot. 22: 153 (1967). i

Homalomena paucinervia Ridl., J. Straits Branch Roy. Asiat. Soc. 44: 175 (1905). $\quad$ i

Homalomena stella P.C.Boyce \& S.Y.Wong, Aroideana 37: 33 (2014). F $\quad$ F

Homalomena vagans P.C.Boyce, Kew Bull. 49: 799 (1994). F

Hottarum truncatum (M.Hotta) Bogner \& Nicolson, Aroideana 1: 72 (1978).

Naiadia zygoseta (S.Y.Wong, S.L.Low \& P.C.Boyce) S.Y.Wong \& P.C.Boyce, $\quad$ i Webbia 72(2): 60 (2018).

Ooia altar S.Y.Wong \& P.C.Boyce, J. Jap. Bot. 91 (supplement): 141 (2016). I iv

Ooia basalticola S.Y.Wong \& P.C.Boyce, J. Jap. Bot. 91 (supplement): 143 (2016). iii/iv

Ooia glans S.Y.Wong \& P.C.Boyce, J. Jap. Bot. 91 (supplement): 145 (2016). iv

Ooia grabowskii (Engl.) S.Y.Wong \& P.C.Boyce, Bot. Stud. (Taipei) 51(4): $545 \quad$ iv (2010).

Ooia havilandii (Engl.) S.Y.Wong \& P.C.Boyce, J. Jap. Bot. 91 (supplement): 149 iv (2016).

Ooia kinabaluensis (Bogner) S.Y.Wong \& P.C.Boyce, Bot. Stud. (Taipei) 51(4): $548 \quad$ iv (2010).

Ooia manduensis (A.Hay \& Bogner) S.Y.Wong \& P.C.Boyce, J. Jap. Bot. 91 (supple- i ment): 156 (2016).

Ooia paxilla P.C.Boyce \& S.Y.Wong, Webbia 68(2): 87 (2013). iii/iv 
Appendix 1. Continuation.

\section{Species}

Sub-

category

Ooia secta S.Y.Wong \& P.C.Boyce, J. Jap. Bot. 91 (supplement): 161 (2016).

Ooia suavis S.Y.Wong \& P.C.Boyce, J. Jap. Bot. 91 (supplement): 163 (2016). iv

Phymatarum borneense M.Hotta, Mem. Coll. Sci. Kyoto Imp. Univ., Ser. B, Biol. $\quad$ i 32(1): 29 (1965).

Piptospatha insignis N.E.Br., Gard. Chron., n.s., 11: 138 (1879).

Piptospatha remiformis Ridl., J. Straits Branch Roy. Asiat. Soc. 49: 52 (1908).

Piptospatha repens H.Okada \& Tsukaya, Acta Phytotax. Geobot. 61(2): 87 (2010).

Piptospatha rigidifolia Engl., Pflanzenr. 55(IV.23Da): 127 (1912).

Pursegloveia aegis S.Y.Wong \& P.C.Boyce, Aroideana 41(2\&3): 28 (2018).

Pursegloveia ashtonii (S.Y.Wong \& P.C.Boyce) S.Y.Wong \& P.C.Boyce, Webbia $\quad$ i 72(2): 69 (2018).

Pursegloveia burttii (Bogner \& Nicolson) S.Y.Wong \& P.C.Boyce, Webbia 72(2): 69 i (2018).

Pursegloveia kazuyae (S.Y.Wong, P.C.Boyce \& S.L.Low) S.Y.Wong \& P.C.Boyce, $\quad$ i Webbia 72(2): 69 (2018).

Pursegloveia minima (H.Okada) S.Y.Wong \& P.C.Boyce, Webbia 72(2): 69 (2018). $\quad$ i Pursegloveia orientalis (S.Y.Wong, P.C.Boyce \& S.L.Low) S.Y.Wong \& P.C.Boyce, i Webbia 72(2): 69 (2018).

Rhaphidophora beccarii (Engl.) Engl., Bot. Jahrb. Syst. 1: 181 (1881).

i

Rhaphidophora fluminea Ridl., J. Straits Branch Roy. Asiat. Soc. 44: 186 (1905). $\quad$ i

Rhaphidophora megasperma Engl., Bot. Jahrb. Syst. 25: 8 (1898). F

Rhaphidophora typha P.C.Boyce, Gard. Bull. Singapore 57: $211(2005)$ i

Rhynchopyle elongata (Engl.) Engl., Bot. Jahrb. Syst. 1: 184 (1881). i

Rhynchopyle impolita (S.Y.Wong, P.C.Boyce \& Bogner) S.Y.Wong \& P.C.Boyce, $\quad$ i Webbia 72(2): 71 (2018). 
Appendix 1. Continuation.

Species

Sub-

category

Rhynchopyle loi (S.Y.Wong \& P.C.Boyce) S.Y.Wong \& P.C.Boyce, Webbia 72(2):

71 (2018).

Rhynchopyle marginata (Engl.) Engl., Bot. Jahrb. Syst. 1: 184 (1881).

Rhynchopyle nivea (P.C Boyce, S.Y.Wong \& Sahal) S.Y.Wong \& P.C.Boyce,

Webbia 72(2): 72 (2018).

Rhynchopyle pileata (S.Y.Wong \& P.C.Boyce) S.Y.Wong \& P.C.Boyce, Webbia 72(2): 72 (2018).

Rhynchopyle viridistigma (S.Y.Wong, P.C.Boyce \& Bogner) S.Y.Wong \&

P.C.Boyce, Webbia 72(2): 73 (2018).

Schismatoglottis ahmadii A.Hay, Telopea 9(1): 102 (2000).

$\mathrm{V}$

Schismatoglottis bulbifera H.Okada, H.Tsukaya \& Y.Mori, Syst. Bot. 24: 62 (1999). v

Schismatoglottis clausula S.Y.Wong, Gard. Bull. Singapore 61(2): 530 (2010). $\quad$ F

Schismatoglottis crypta P.C.Boyce \& S.Y.Wong, Webbia 69(2): 225 (2014). i

Schismatoglottis cyria P.C.Boyce, Kew Bull. 49: 796 (1994). i(?)

Schismatoglottis dulosa S.Y.Wong, Gard. Bull. Singapore 61(2): 533 (2010). i

Schismatoglottis gillianiae P.C.Boyce, Kew Bull. 49: 793 (1994). i

Schismatoglottis hayana Bogner \& P.C.Boyce, Gard. Bull. Singapore 60(2): 1 (2009). i

Schismatoglottis heterodoxa S.Y.Wong, Willdenowia 42: 255 (2012). iv

Schismatoglottis iliata P.C.Boyce \& S.Y.Wong, Willdenowia 44: 6(2014). i

Schismatoglottis jelandii P.C.Boyce \& S.Y.Wong, Gard. Bull. Singapore 58: 7 i (2006).

Schismatoglottis larynx S.Y.Wong \& P.C.Boyce, Aroideana 39(2): 18 (2016). $\quad$ i

Schismatoglottis maelii P.C.Boyce \& S.Y.Wong, Gard. Bull. Singapore 58: $14 \quad$ F 
Appendix 1. Continuation.

\section{Species}

Sub-

category

Schismatoglottis mayoana Bogner \& M.Hotta, Acta Phytotax. Geobot. 34: 48 (1983). F

Schismatoglottis multiflora Ridl., J. Straits Branch Roy. Asiat. Soc. 44: 181 (1905). $\quad$ i

Schismatoglottis nicolsonii A.Hay, Telopea 9(1): 95 (2000). $\quad$ F

Schismatoglottis persistens P.C.Boyce \& S.Y.Wong, Willdenowia 44: 247 (2014). $\quad$ F

Schismatoglottis petradoxa S.Y.Wong \& P.C.Boyce, Aroideana 37E(2): 19 (2014). $\quad$ i

$\begin{array}{ll}\text { Schismatoglottis pudenda A.Hay, Telopea 9(1): } 98 \text { (2000). F } & \text { F }\end{array}$

Schismatoglottis rejangica S.Y.Wong \& P.C.Boyce, Aroideana 39(2): 22 (2016). $\quad$ i

Schismatoglottis roseospatha Bogner, Aqua Pl. 1988: 96 (1988). i

Schismatoglottis tegorae P.C.Boyce \& S.Y.Wong, Webbia 69(2): 230 (2014). $\quad$ i

Schismatoglottis thelephora S.Y.Wong, P.C.Boyce \& S.L.Low, Gard. Bull. Singapore i 64(1): 266 (2012).

Schismatoglottis tseui S.Y.Wong \& P.C.Boyce, Aroideana 37E(2): 22 (2014). $\quad$ ii(?)

Schottariella mirifica P.C.Boyce \& S.Y.Wong, Bot. Stud. (Taipei) 50(2): 270 (2009). $\quad$ i

Schottarum josefii (A.Hay) P.C.Boyce, S.Y.Wong \& S.L.Low, Pl. Syst. Evol. 300(4): $\quad$ i 614 (2014).

Schottarum sarikeense (Bogner \& M.Hotta) P.C.Boyce \& S.Y.Wong, Bot. Stud. (Tai- i pei) 49(4): 395 (2008).

Tawaia sabahensis (S.Y.Wong, S.L.Low \& P.C.Boyce) S.Y.Wong \& P.C.Boyce, $\quad$ i Webbia 72(2): 79 (2018).

Toga alatensis (S.Y.Wong, S.L.Low \& P.C.Boyce) S.Y.Wong \& P.C.Boyce, Webbia i 72(2): 81 (2018).

Toga hippocrepis (S.Y.Wong \& P.C.Boyce) S.Y.Wong \& P.C.Boyce, Webbia 72(2): i 81 (2018).

Toga perplexa (S.Y.Wong, S.L.Low \& P.C.Boyce) S.Y.Wong \& P.C.Boyce, Webbia i 72(2): 81 (2018).

Toga rostrata (Bogner \& A.Hay) S.Y.Wong \& P.C.Boyce, Webbia 72(2): 81 (2018). $\quad$ i 
Appendix 1. Continuation.

\begin{tabular}{lc}
\hline Species & $\begin{array}{l}\text { Sub- } \\
\text { category }\end{array}$ \\
\hline $\begin{array}{l}\text { Toga surukensis (S.Y.Wong, S.L.Low \& P.C.Boyce) S.Y.Wong \& P.C.Boyce, } \\
\text { Webbia 72(2): 81 (2018). }\end{array}$ & $\mathrm{i}$ \\
$\begin{array}{l}\text { Toga unca (S.Y.Wong\& P.C.Boyce) S.Y.Wong \& P.C.Boyce, Webbia 72(2): } 82 \\
\text { (2018). }\end{array}$ & $\mathrm{i}$ \\
\hline
\end{tabular}

